DOI: $10.1515 / \mathrm{rpp}-2016-0027$

Doctor of Pedagogical Sciences, Full Professor, OLENA OGIENKO A. S. Makarenko Sumy State Pedagogical University, Ukraine Address: 87 Romenska St., Sumy, 40002, Ukraine E-mail: el.ogienko@gmail.com

\title{
PROFESSIONAL TRAINING OF ECONOMISTS AT POLISH UNIVERSITIES
}

\begin{abstract}
Polish experience in professional training of economists at university has been generalized. Structural, content and procedural peculiarities of the training have been defined. It has been proved that key factors for reforming economic education in Poland are globalization, internationalization, integration, technologization and informatization. It has been found out that forming of economic competency is based on the competency-based and personality-based approaches that allow to direct the educational process at a student as an active subject of learning, to create conditions for his/her creative potential development, to educate a competent specialist possessing all the competencies needed in professional activity. The influence of Polish universities' integration into European system of student exchange on the quality of future specialists' training has been revealed. Flexibility and variety of syllabi and curricula of economists' professional training at Polish universities have been emphasized. Among perspective teaching methods we have singled out situational modeling as it allows to create situations at most approximated to those in professional activity, is oriented at co-creation and teamwork. It has been found out that the peculiarities of economists' professional training at Polish universities are flexibility, diversification, standardization, personalization and adaptation to modern labour market. It has been proved that the result of economists' professional training at Polish universities is a highly qualified specialist able to adapt to dramatic changes in economy and society.

Key words: economic education, university, Poland, professional training of economists, competency, curriculum, flexibility, diversification.
\end{abstract}

\section{INTRODUCTION}

Integration and globalization processes directly affecting social and economic development of Ukraine cause reformative changes to educational guidelines, prioritizing basic human values, orienting to real needs of the society. In this context the establishment of economic education in Ukraine that would correspond to the requirements of market economy and the transition to a democratic and constitutional state is of great importance (Данилевич, 2006). Thereby, the Conception of Economic Education Development in Ukraine has been approved. Based on it the understanding of the fact that the development of economy is mainly caused by a pattern of an individual's vital activity, worldview and social behaviour is the main paradigm of economic education (Законы Украины. Информационно-правовой портал, 2007). According to the data presented by State Statistics Service of Ukraine higher economic education is extremely prestigious and popular in Ukraine nowadays. Thus, a share of the specialists obtaining higher economic education is constantly increasing. In 2010 it comprised $17,4 \%$ of all the graduates, in $2011-28,7$ \%, in 2014 - 31,2 \% (Державний комітет статистики України, 2016). However, in terms of Ukraine's integration into the European and global educational space, 
mobility provision, inclusion into the information society appears the need to take into account general trends in economic education development in Europe, peculiarities of future economists' professional training, namely, progressive ideas of Polish experience as Poland is an active member of European Union and has great pedagogical achievements and developed economic education.

\section{THE AIM OF THE STUDY}

The aim of the study is to generalize Polish experience in professional training of economists at university and to define its structural, content and procedural peculiarities.

\section{THEORETICAL FRAMEWORK AND RESEARCH METHODS}

Theoretical framework of the research is based on the works by native (V. Andrushchenko, N. Bidyuk, V. Kremen, V. Lugovyi, N. Nychkalo, O. Padalka, T. Poyasok, H. Tovkanets, O. Romanovskyi, M. Vachevskyi) and foreign (Kh. Khort, L. Klein, E. László, J. Malach, P. Matei, S. Mendlovic, V. Peniak, B. Pleskovych, I. Proukh, J. Schumpeter) scholars dedicated to the problem of higher education development and, in particular, higher economic education. In addition, works by Ya. Beksyak, B. Garbachyk, Kh. Gulda, U. Gzhelonska, I. Durlik, Ye. Ivanchenko, E. Khmeletska, A. Maycher-Teleon, T. Poyasok, M. Vachevskyi, B. Vavzhynyak, L. Volodarska-Zola on professional training of economists have contributed to the research performed.

To achieve the aim of the study we have used such theoretical methods as analysis, synthesis, systematization of scientific literature and regulations on professional training of future economists; context analysis and comparison of syllabi and curricula; generalization.

\section{RESULTS}

In the context of the processes taking place in higher education in Poland and taking into account scientific achievements of scholars and practicians it is necessary to indicate that the development of higher economic education is based on historical, cultural, spiritual and moral traditions; is directed at profound analysis of economic processes stipulating for the forming of socially-oriented economy; is followed by the review of educational strategic priorities and values, methodological and methodical principles, the specification of functions, the appearance of new ideas and approaches to the development of higher economic education (Edward, Steen, Domański, 1997).

The modernization of Polish education system and, in particular, economic education was launched after the democratic revolution and the transition to market economy in 1989. The idea of justice in the interaction between global economy and labour market was rather important for education reforms as in terms of globalization and internationalization the need for social development was increasing.

In the very context L. Volodarska-Zola assumes that professional training of future economists in higher education institutions should be realized on economic, econometric, humanitarian and technical aspects and provide for students' obtaining both professional knowledge of organization, management, economy, finance, marketing and humanitities (Влодарска-Зола, 2003). The emphasis on humanities is caused by strengthening the role of human capital as well encouraging to reveal and use the potential of an individual. At the same time professional training of future economists is to coresspond to demands and requirements of labour market, take into account those social, economic and technological changes occuring not only within the country but in the world, too. Thus, the main factors affecting the organization of specialists' professional training in Poland, are, first of all, the competitiveness of Polish economy in the system of global economy, the dynamics of market criteria and shifts in labour market. 
The reforming of economic education in Poland is based on the democratization of educational space and the decentralization of education management. That is why one of the structural peculiarities of future economists' professional training is the diversification of education institutions. Education institutions comprise universities and academies, in particular, Warsaw Economic University, Lublin University of Technology, The University of Economy in Bydgoszcz, Wroclaw University of Economics, Crakow University of Economics, University of Economics in Katowice, Academy of Economics in Bialystok, Academy of Management and Administration in Opole, etc. Higher education of Poland is based on the three-cycle structure, namely, Bachelor (Licencjat, Inzynier), Master (Magister) and Doctor of Sciences (Doktor) (Загородня, 2015).

We believe it necessary to indicate that Polish higher education institutions are included into European System of Student Exchange that significantly influences the quality of future specialists' professional training as Polish students may study at leading universities of the world.

It should be mentioned that Polish education system and, in particular, economic education function according to the European Credit Transfer and Accumulation System (ECTS) and International Standard Classification of Education (ISCED) that enable the development of economic education so that the systems of specialists' training in European countries may be approximated (Вачевський, 2006).

Professional training of economists at Polish universities is based on the competencybased approach that provides for a new vision of goals and assessment of professional training results, emphasizes the forming of a competent specialist possessing the competencies needed in professional activity.

The importance and significance of a competency-based approach in higher education were discussed at the sypmosium on "The Key Competencies for Europe" held by the Council of Europe and declared in "Memorandum on Lifelong Learning" (Hutmacher, 1997).

Based on a competency-based approach one can define professional competencies of economists and they are regarded as:

- quality characteristics of an individual that covers the system of scientific and theoretical knowledge, in particular, of economy, professional abilities and skills, experience, interest and the need to be a competent economist (О. Булавенко, В. Миханєв);

- an integrity of knowledge, abilities, skills and experience obtained during learning that ensure the specialists' suitability for professional activity and life in the fastchanging society ( $\mathrm{C}$. Іванченко);

- a unity of three components: economic (a competence related to processing information of accounting, economic and financial direction); computer (a competence related to dealing with computer technics and programmes); productive and activity-based (a competence related to the use of modern innovative technologies according to accounting and economic information) (М. Теловата) (Шевчук, 2013; Górniak, 2012).

So, the competency of economists should be considered in the unity of personalityand activity-based manifestations of the phenomenon that perfectly combines key competencies, professionalism and the social competency of an individual.

A competency-based approach is crucial in defining the content of economists' professional training at Polish universities as it is based on the needs of labour market. At the same time Polish scholars (Górniak, 2012; Edward, Steen, Domański, 1997) consider this approach to be one of the key aspects in developing standards of education quality as it is a motivational and target factor for a future specialist. 
We have found out that alongside with a competency-based approach a personalitybased approach also plays an important role in professional training of economists at Polish universities as it orients the educational process to a personality as a goal, subject, outcome and criterion of its efficiency, emphasizes the need to create the conditions to develop students' creative potential, inspire them to be active subjects and recognize the uniqeness of their subjective experience as an essential source of an individual vital activity.

So, a personality-based approach is becoming extremely important for modern evolving universities. M. Malewski states that there is an opposition between "wisdom and an ability" caused by a university's transition from "a model of community" to "a model of production" (Загородня, 2015). A modern university is approaching to a market model based on market criteria and is becoming a form of education services aimed at fulfilling students' needs.

It has been found out that the content of economists' professional training is defined by educational standards presupposing two cycles of training. The first cycle covers 6 semesters and the amount of credits should not be less than 180. Students obtain theoretical economic knowledge, practical skills and abilities.

The second semester consists of 4 semesters and the necessary amount of credits counts to 120. Students now have prodound knowledge of economic subjects, are acquainted with methods of modeling analysis and economic phenomena prognosing and are able to work in different segments of the European market (Вачевський, 2006; Górniak, 2012; Edward, Steen, Domański, 1997).

For instance, the University of Rzeszow offers economic education in economy and entrepreneurship; economy of business services; economy as a factor of local and regional development; European economic integration. After graduation graduates may work in economic establishments and organizations as well as bodies of public administration (Uniwersytet Rzeszowski, 2016).

In our opinion, rather perspective is the implementation of personalized education launched at Crakow University of Economics as it provides students with an opportunity to choose subjects, build an indivudual educational trajectory according to their interests, needs and expectations (Uniwersytet Ekonomiczny w Krakowie, 2016).

While analyzing curricula we have singled out the requirements to forming of the content of future economists' professional training, namely, diversification, integration, standardization, interdisciplinarity, variety, personalization.

The flexibility of Bachelor's and Master's professional training is caused by the content and structure of a syllabus. In addition, the study of humanitaran and social and economic courses stipulates for forming of a future specialist's worldview, defining of his/her personal and professional tasks. It should be noted that there is no division into core and elective courses. The university's scientific council approves those courses that are to be included into the syllabus.

At the same time the reforming of economic education in Poland is changing approaches to the organization and use of forms and methods at the universities and is stipulating for the implementation of new innovative teaching technologies and new practiceoriented methodologies. The emphasis is very much on independent work of students and their involving into project activities.

Polish scholars draw attention to pedagogical opportunities of using a method of situational modeling during future economists' training. This method was first applied at Harvard business school and nowadays the case study analysis comprises almost $90 \%$ of the educational process at American business schools. Thus, instructors model a certain 
situation that is at most approximated to practical issues and needs to be solved (Uniwersytet Ekonomiczny w Krakowie, 2016).

It should be mentioned that at Polish universities various types of situational modeling are used, namely:

- Harvard case method that provides for the analysis of a particular situation requiring certain analytical thinking or resolving conflict;

- a method of project design allows, first of all, to solve specific economic tasks and, second of all, improves teamwork;

- Pilers' method or an incident resolution method is based on resolving a so-called mini-case (incident) that is not inherent in a specialist's professional activity. Furthemore, information about it is rather limited and students suggest their own vision and solutions, participate in discussions, brainstorm and take final decisions;

- in-basket test that allows to form must-have qualities of the modern manager through modeling manageable activities;

- a method of gradual familiarization with the case - the information about a certain situation is given in parts and after it has been discussed and the decision has been taken the next block of information is provided and its analysis influences final resolving the situation (Якимова, 2010; Edward, Steen, Domański, 1997; Uniwersytet Ekonomiczny w Krakowie, 2016). universities.

Based on a method of situational modeling a method of imitations is used at Polish

At Warsaw Economic University a method of situational modeling is widely used, too (Ammerman, Gaweł, Pietrzykowski, Rauktienè, Williamson, 2012). Students are offered certain projects based on real problems that can be solved by means of an interdisciplinary approach and the application of knowledge of different fields, namely, economy, management, marketing, etc. At the same time students are encouraged to establish relations with organizations, enterprises thus approximating learning to the conditions of future professional activity.

\section{CONCLUSIONS}

Based on the above it should be mentioned that the study of Polish experience in professional training of economists allows to conclude that it is directed at forming future specialists' economic thinking, professional competencies and abilities to regularly update and enhance the level of knowledge. Leading factors influencing professional training of specialists are: the need to ensure competitiveness of Polish economy, response to globalization and integration challenges, introduction of new market criteria; the dynamics of changes of labour market requirements. The network of higher education institutions providing professional training of economists is characterized by variety and different directions of professional training (structural peculiarities). Competency-based and personality-based approaches are defining in professional training of economists at Polish universities. Syllabi and curricula take into account perspective needs of economy and enterprises, national and international labour market; provide future specialists with knowledge and abilities needed for effective professional activity, encourage to realize the importance and necessity of lifelong learning. Content peculiarities of economists' professional training are flexibility, diversification, standardization, personalization and adaptation to modern labour market. The efficiency of specialists' professional training at Polish universities mostly depends on the use of innovative technologies and methods of teaching and learning. In the educational process a method of situational modeling is widely used. The rapid development of economists' professional training at Polish 
universities is ensured by the implementation of a practice-oriented paradigm based on the well-aimed combination, interconnection and mutual supplement of knowledge, abilities, skills, experience and competency.

Rather perspective for further researches we consider the study of the content peculiarities of curricula for professional training of economists at Polish higher education institutions, criteria for the assessment of the quality of Bachelor's and Master's in Economy training in the system of Polish higher education system.

\section{REFERENCES}

1. Górniak, J. (2012). Competencies as the Key to the Development of Poland: the Report Concluding the Second Round of the Study of Human Capital in Poland Conducted in 2011. Warszawa : Polska Agencja Rozwoju Przedsiębiorczości, 237 p.

2. Edward, K., Steen, T. P., Domański, S. R. (1997). The Reform of Higher Economic Education in Poland. The Journal of Economic Education, Volume 28, Issue 4, pp. 377-382.

3. Hutmacher, W. (1997). Key Competencies for Europe. Report of the Symposium. Strasbourg : Council for Cultural Cooperation, $72 \mathrm{p}$.

4. Ammerman, P., Gaweł, A., Pietrzykowski, M., Rauktiene, R., Williamson, T. (2012). The Case Study method in Business Education: Textbook. Poznań : Bogucki Wydawnictwo Naukowe, 116 p.

5. Uniwersytet Ekonomiczny w Krakowie [Cracow University of Economy]. (2016). Retrieved 14.09.2016 from : https://www.uek.krakow.pl/.

6. Uniwersytet Rzeszowski [University of Rzeszow]. (2016). Ekonomii [Economy]. Retrieved 16.09.2016 from : http://www.ur.edu.pl/wydzialy/ekonomii.

7. Szkoła Główna Handlowa w Warszawie (SGH) [The Warsaw School of Economics]. (2016). Abount University. Retrieved 18.09.2016 from : http://uczelnia.sgh.waw. $\mathrm{pl} / \mathrm{en} /$ Pages/default.aspx.

8. Якимова, Л. А.(2010). Активізація навчального процесу у сучасній вищій школі: метод. огляд [The Activization of the Educational Process in Modern Higher Education Institutions: Methodological Review]. К. : ДП “Вид. дім “Персонал”, 32 р. (in Ukrainian).

9. Вачевський, М. (2006). Сучасна економічна освіта у країнах Західної Свропи: формування професійних компетенцій [Modern Economic Education in Western European Countries: Forming of Professional Competences]. Рідна школа [Native School], No 3, pp. 71-74 (in Ukrainian).

10. Влодарска-Зола, Л. (2003). Професійна підготовка майбутніх менеджерів у вищих технічних навчальних закладах [Professional Training of Future Managers in Higher Technical Education Institutions]. Abstract of Thesis for PhD. K. : Iн-T педагогіки та психології професійної освіти АПН України, 20 р. (in Ukrainian).

11. Загородня, А. А. (2015). Зміст професійної підготовки фахівців економічної галузі в Республіці Польща [The Content of Economists' Professional Training in Poland]. Проблеми економіки [Problems of Economy], No 4, pp. 25-29 (in Ukrainian).

12. Законы Украины. Информационно-правовой портал [Laws of Ukraine. Legal Information Portal]. (2007). Конщепція розвитку економічної освіти в Україні [The Conception of Economic Education Development in Ukraine]. Retrieved 12.09.2016 from : http://www.uazakon.com/document/fpart82/idx82748.htm.

13. Державний комітет статистики України [State Statistics Service of Ukraine]. (2016). Основні показники діяльності вищих навчальних закладів України на 
початок 2010/11, 2011/2012, 2012/2013 навчального року [Main Indicators of Ukrainian Higher Education Institutions' Activities at the Beginning of 2010/11, 2011/2012, 2012/2013 Study Years]. Retrieved 10.09.2016 from : http://www.ukrstat.gov.ua//druk/katalog/ .

14. Данилевич, В. Д. (2006). Сучасна економічна освіта: Украӥна $i$ Болонський процес [Modern Economic Education: Ukraine and Bologna Process]. К., 326 p. (in Ukrainian).

15. Шевчук, О. (2013). Основні підходи до підготовки майбутніх фахівців фінансово-економічного напряму в Україні [Main Approaches to Training of Future Economists and Financiers in Ukraine]. Науковий вісник Мелітопольського державного педагогічного університету. Серія: Педагогіка [Scientific Bulletin of Melitopol State Pedagogical University. Series: Pedagogy], No 2 (11), pp. 200-207 (in Ukrainian). 